\title{
Determinants of equity crowdfunding success
}

\author{
Milica Latinovic \\ Department of Financial Management and Accounting \\ University of Belgrade, Faculty of Organizational Sciences \\ Belgrade, Republic of Serbia \\ milica.latinovic@fon.bg.ac.rs
}

\author{
Vesna Bogojevic Arsic \\ Department of Financial Management and Accounting \\ University of Belgrade, Faculty of Organizational Sciences \\ Belgrade, Republic of Serbia \\ vesna.bogojevic.arsic@fon.bg.ac.rs
}

\begin{abstract}
Equity crowdfunding represents an alternative online financing source. Small, nonaccredited investors can back different ventures and earn financial, strategic, and social returns. We find that equity crowdfunding success is dependent on team size, financing target, and the number of backers.
\end{abstract} factor

Keywords - equity crowdfunding, platform, success

\section{INTRODUCTION}

Reference [1, p. 1] define "crowdfunding as a method of collecting many small contributions, by means of an online funding platform, to finance or capitalize a popular enterprise". There are four models of crowdfunding: reward-based, equity-based, lending-based, and donation-based $[2,3]$. In rewardbased crowdfunding, investors provide funding to individuals, projects or companies in exchange for nonmonetary products or rewards, based on the size of their investment [3]. Equity crowdfunding represents the offering and sale of equity-based securities to a large number of accredited and nonaccredited investors, where those offerings can be made through funding portals or broker-dealers [1]. Lending-based crowdfunding is twofold. It can be peer-to-peer consumer lending and peer-to-peer business lending, where individual or institutional funders provide a loan to a consumer or a business borrower [2, 3]. Donation-based crowdfunding assumes that donors provide funding to individuals, projects, or companies based on philanthropic motivations with no expectations of monetary or material return [3].

We can differentiate between "all or nothing" and "keep it all" platforms "in the press" [4]. Furthermore, crowdfunding platforms charge certain fees. For example, SEEDRS, one of the most famous equity crowdfunding platforms in the UK, charges a fee to ventures as well as to the investors. The fee of $7.5 \%$ is charged to a successfully funded business and investor's profits [5].

Equity crowdfunding is most developed in the United Kingdom due to the regulatory framework established in 2011. Investors in the UK have tax incentives through the Seed Enterprise Investment Scheme (SEIS) and the Enterprise Investment Scheme (EIS) [5]. For investors in the United States of America, equity crowdfunding became legal with the introduction of the new law in 2012 - The Jumpstart Our Business Start-ups (JOBS) Act [1], but which was approved by Securities and Exchange Commission only in 2015 [5]. This Act enabled start-ups' to sell securities through online portals to all investors and not just to accredited ones. Through online portals, start-ups can raise up to $1.000 .000 \$$, the number of investors is not limited, and investment can be $1.000 \$$ or less. Start-ups can go bankrupt, some of them can be successful and stay small, and only a small portion of start-ups survive and grow. All types of investors can enter this market, and they have to be aware of the exit strategies that exist, like Initial Public Offerings (IPO), management buybacks, acquisitions, and sale on online secondary markets for crowdfunded equity [1].

Equity crowdfunding gives an opportunity to the investors to earn financial, strategical (they bring expertise), and social returns (community development, job creation, supporting good ideas, building relationships with various stakeholders) [1].

Characteristic of the equity crowdfunding is that there are two market mechanisms which are in use to allocate financial securities to the investors. First come first serve mechanism assumes that prices are constant during the campaign. Investors may bid sooner in the campaign to assure that they will receive securities. The Auction mechanism assumes that investors will hold their bids until the end of the campaign. The market mechanism can determine investors' behaviour and the dynamics of their investments [6].

Crowdfunding is a new type of financing which is gaining in popularity in recent years'. Especially this is true since many developed markets introduced legislation which enables small and nonaccredited investors to back start-ups. In this paper, we focus on one type of crowdfunding - equity crowdfunding. We have tried to address the issue of success factors in equity crowdfunding since the literature on this aspect is still scarce. A certain number of research regarding success factors connected to reward-based crowdfunding platforms are performed. Literature about success factors in equity crowdfunding is more modest, and we tried to fill that gap.

The rest of the paper is structured as follows: the second part is devoted to fundamental concepts of the equity crowdfunding; in the third part, empirical research on success factors is presented and in the fourth part discussion, along with a conclusion is given. 


\section{FOUNDATIONS OF EQUITY CROWDFUNDING}

\section{A. New Venture Financing Life cycle}

Lack of capital presents a tremendous obstacle for growth. Capital requirements and sources of funds can be different depending on a venture's stage of a life cycle [7]. There are several stages in the new venture life cycle: initial concept and seed stage (pre-startup), startup (early) stage, expansion stage, late-stage, and IPO [7, 8]. Conventional sources of financing that are available to new ventures throughout its life cycle are family, friends, angel investors, venture capitalists, and seed funding. An alternative model that is coming into prominence in recent years is crowdfunding [8]. Reference [8] notices that startups, entrepreneurial firms with new and innovative business ideas [7, 9], are hesitant to employ crowdfunding practices. This is due to their unawareness on how different types of crowdfunding practices can add value in different stages of its life cycle. Financing needs in a seed-stage for every venture are considerable. Seed stage assumes a substantial need for capital that entrepreneurs' need for developing a prototype or feasibility study of a product/service. Main investors in this stage are family members or business angels. Research grants and crowdfunding are other available options for prestartup stage [7, 9]. Donation-based crowdfunding is appropriate for this stage. Funding goals in this type of crowdfunding are low, and donations are small, yet much-needed capital can be raised, and venture can progress to the next stage in its life cycle [8].

Start-up stage assumes that funds are needed to refine the prototype into a minimum viable product, hire employees, establish the product in the market, and to conduct marketing plan for successful launch [8]. Management is present and operational with an established business model [9]. At this stage, certain grants and debt could be available to the ventures. Also, business angels, venture capitalists, and crowdfunding represent a funding source option for start-ups [7]. The most convenient crowdfunding model in start-up stage is lending-based crowdfunding. A key goal of the start-up stage of a venture is to validate a product and to determine its market fit, which requires more funds than pre-startup stage. Lending platforms require higher minimum investment, which is in aligning with higher capital requirements [8].

After the start-up stage, if the venture continues to grow at a high rate it enters the expansion stage. The Expansion stage assumes that capital is used to intensify production or to expand into different markets, to develop new products or services, to finance the acquisition or finance an increase in working capital [7, 9]. Financing at this stage is used for continuing growth, scaling operations and processes for venture to remain profitable. Since this stage is the most capital intensive, it is reasonable to offer investors some financial return. Therefore, equity crowdfunding is most appropriate model in the expansion stage [8].

\section{B. Securities}

Different jurisdictions have different laws and financial securities offered in the equity crowdfunding campaigns are diverse.

In the United States of America, Title III of the JOBS Act authorizes equity crowdfunding and permits accredited, as well as nonaccredited investors to make investments on the funding portals. There are two kinds of portals, crowdfunding platforms and brokerdealers platforms which are open for the crowd. Regulation D regulates platforms that are open only to the accredited investors [1].

Title III equity offerings are commonly in the form of corporate stocks, limited liability company membership units, and convertible debt. Stocks offerings of a start-up can be in the form of common or preferred stocks. Preferred shares are more common since they enable founders and managers of start-ups to maintain control. Preferred stocks of such a risky venture can be more beneficial to the investors since they have liquidation preferences, and usually they are convertible into the common shares when venture reaches certain milestones. Also, preferred shares might not include conversion rights, and in the case of the acquisition, investors would not realize high returns. Different classes of the preferred shares might be available to the investors, where each series entitles investors to different rights and they are issued in a successive round of equity financing [1].

In the United Kingdom, on one of most wellknown equity crowdfunding platforms - Crowdcube, equity offerings are shares in a private limited liability company [6]. In Germany, when start-up is financing its operations through equity crowdfunding, they use mezzanine financial instruments or silent partnerships [6]. Crowdfunding portals in Germany (Quasi-equity) provide standardized contracts to the crowd, based on the capital needs of the start-up and agreed valuation. Investors hold the right to receive pro-rata payment of the start-up's future cash flows and do not hold voting right. Their maturity is from three to seven years, and they cannot be traded on the secondary markets. These mezzanine financial instruments are considered above ordinary shares and shareholder loans, but under ordinary liabilities, if we look into seniority [6].

\section{Researches into Equity Crowdfunding}

Equity crowdfunding is new, interesting, yet still not much-researched subject. Each research is valuable because it contributes to the theoretical foundation and determination of interactions that exist in these markets.

Reference [6] investigate how different market mechanisms affect investments, and they find that auction introduce late investments while first come first serve to stimulate investments during the first few days. Their results are based on the equity crowdfunding platforms in Germany.

According to the collective attention effect, first few days would attract most investments. Investors 
react to the information during the campaign, but they are under the influence of the collective network interactions. Herding behaviour is also present at the start-up level, and investors react to the company updates and investor's comments posted on the platform [6].

Reference [5] study UK's equity crowdfunding and find that successful campaigns are overfunded; they start with a strong backers support and have at least one large investor. When compared to rewardbased crowdfunding, equity projects have higher goals, more backers, yet lower success rates. They conclude that crowdfunding will substitute other sources of financing.

Reference [10] show in the sample of the UK's equity crowdfunding platform Crowdcube that the motivations of start-ups to engage in this type of financing is in align with the pecking order theory. No matter if we look at the corporations listed on some stock exchanges or seed companies, they always use equity as a last resort. Equity financing is selected after internal resources and debt financing.

Reference [11], based on the data from the UK's Crowdcube, find that human capital is important in equity crowdfunding. Team characteristics like education, professional experience, gender, as well as the number of investors, influence the total amount raised. Reference [12], based on the sample of US equity crowdfunding campaigns, also find that gender has an important role when looking at the amount of capital raised. When a woman is in charge of the project, it raises significantly less funding. Besides gender, "in press" [13] find that different networks in all phases of the equity crowdfunding process, either personal or made through the business and platform are crucial for successfulness of this process.

Reference [14] investigated Nordic equity crowdfunding platform and find that success factors of this type of crowdfunding are social networks, early funding collected from private networks, the size of the minimum allowed investment. Investment motives of the crowd in the equity crowdfunding are similar as in other types of crowdfunding but different to venture capital and business angels. Funding target, duration and business to customer orientation of the campaign, as well as the amount of the information provided in the pitch drive the number of the backers. Reference [15] based on the US sample of equity crowdfunding campaigns find that completed product/service will be more successful, as well as ventures with large corporate clients and/or well-established that already attracted angel and venture capital investment. Large entrepreneurial teams attract more investments. However, whether venture has a patent, or whether an entrepreneur is serial or experienced does not influence campaign success.

\section{EMPIRICAL INVESTIGATION}

\section{A. Data description}

In order to make a contribution in determining relevant start-up activities that can lead to an increase in the amount raised and to learn what motivates investors to back start-up projects, we hand-collected data from the biggest and most well-established equity crowdfunding platform in Europe - Crowdcube. Data was gathered in the period starting from $18^{\text {th }}$ of March 2019. till the $27^{\text {th }}$ of March 2019. During this ten-day period, data was collected for 35 projects that were active on the $18^{\text {th }}$ of March. Two of them expired almost right from the start of this period, so they are removed from the sample. More projects were added daily on the platform, but data were gathered for the initial sample available on the first day of the data collection period. Crowdcube recognizes seed, early, and growth stage of the investment opportunities offered on its platform. In Table, I summary of the projects' data is presented.

As can be seen from Table I, there is the same number of seed, and early investment projects and the number of growth projects is almost two times less. Such results are not in accordance with the findings of [8], who connect ventures lifecycle phase and the optimal type of crowdfunding. We should expect to see the majority of the Growth projects on this platform. However, [8] argues that most ventures are unaware of the added value potential of each type of crowdfunding.

Projects that are in the start-up phase have the highest average defined target amount. This result is expected since each subsequent phase in the venture's lifecycle needs more financing in order to venture to further grow and expand.

The average number of investors are highest again in a growth phase. By this time, investors are already familiar with a venture and are more secure to make an investment. Projects in early and growth phase are, on average overfunded.

On average, the highest number of team members are in the group of early projects. However, teams are very similar in size in different stages of the lifecycle. On average, number of females is very low comparing to the number of men in the team.

TABLE I. SUMmary OF THE PROJECTS' DATA

\begin{tabular}{|c|c|c|c|c|c|c|c|c|c|c|c|}
\hline $\begin{array}{c}\text { Venture } \\
\text { lifecycle } \\
\text { phase }\end{array}$ & $\begin{array}{c}\text { Num. } \\
\text { of } \\
\text { proj. }\end{array}$ & $\begin{array}{l}\text { Av. } \\
\text { Target } \\
(\mathfrak{f})\end{array}$ & $\begin{array}{c}\text { Av. } \\
\text { Num. } \\
\text { of } \\
\text { inv. }\end{array}$ & $\begin{array}{c}\text { Av. } \% \text { of the } \\
\text { target } \\
\text { amount } \\
\text { raised }\end{array}$ & $\begin{array}{c}\text { Av. } \\
\text { Num. } \\
\text { of } \\
\text { team } \\
\text { mem. }\end{array}$ & $\begin{array}{c}\text { Av. } \\
\text { Num. } \\
\text { of } \\
\text { males }\end{array}$ & $\begin{array}{c}\text { Av. } \\
\text { Num. } \\
\text { of } \\
\text { females }\end{array}$ & $\begin{array}{l}\text { Av. } \\
\text { Daily } \\
\text { views }\end{array}$ & $\begin{array}{c}\text { Av. Num. } \\
\text { of } \\
\text { followers }\end{array}$ & $\begin{array}{c}\text { Num. } \\
\text { Of } \\
\text { company } \\
\text { updates }\end{array}$ & $\begin{array}{c}\text { Num. of } \\
\text { inv. } \\
\text { discussio } \\
\text { ns }\end{array}$ \\
\hline Seed & 13 & 216.692 & 158 & $60 \%$ & 5 & 4 & 1 & 116 & 306 & 7 & 8 \\
\hline Early & 13 & 320.726 & 175 & $182 \%$ & 6 & 5 & 1 & 136 & 392 & 10 & 12 \\
\hline
\end{tabular}




\begin{tabular}{|c|c|c|c|c|c|c|c|c|c|c|c|}
\hline $\begin{array}{c}\text { Venture } \\
\text { lifecycle } \\
\text { phase }\end{array}$ & $\begin{array}{c}\text { Num. } \\
\text { of } \\
\text { proj. }\end{array}$ & $\begin{array}{c}\text { Av. } \\
\text { Target } \\
(f)\end{array}$ & $\begin{array}{c}\text { Av. } \\
\text { Num. } \\
\text { of } \\
\text { inv. }\end{array}$ & $\begin{array}{c}\text { Av. } \% \text { of the } \\
\text { target } \\
\text { amount } \\
\text { raised }\end{array}$ & $\begin{array}{c}\text { Av. } \\
\text { Num. } \\
\text { of } \\
\text { team } \\
\text { mem. }\end{array}$ & $\begin{array}{c}\text { Av. } \\
\text { Num. } \\
\text { of } \\
\text { males }\end{array}$ & $\begin{array}{c}\text { Av. } \\
\text { Num. } \\
\text { of } \\
\text { females }\end{array}$ & $\begin{array}{l}\text { Av. } \\
\text { Daily } \\
\text { views }\end{array}$ & $\begin{array}{l}\text { Av. Num. } \\
\text { of } \\
\text { followers }\end{array}$ & $\begin{array}{c}\text { Num. } \\
\text { Of } \\
\text { company } \\
\text { updates }\end{array}$ & $\begin{array}{c}\text { Num. of } \\
\text { inv. } \\
\text { discussio } \\
\text { ns }\end{array}$ \\
\hline Seed & 13 & 216.692 & 158 & $60 \%$ & 5 & 4 & 1 & 116 & 306 & 7 & 8 \\
\hline Growth & 7 & 1.107 .143 & 612 & $116 \%$ & 4 & 3 & 1 & 512 & 833 & 8 & 24 \\
\hline
\end{tabular}

Maybe such findings are connected to the results of the prior studies [12], which found that projects with a female leading the team experienced a lower success rate. A number of daily views and a daily number of followers vary, depending on the lifecycle phase. Companies make most updates for early stage projects and investors discuss on the average the most about growth projects. Valuation is always an important subject since valuation models are not that developed. Generally, there is not that much publicly available data for start-ups like it is the case with wellestablished listed companies.

\section{B. Model description and empirical results}

In order to contribute to the findings and give an answer to the question of what makes equity crowdfunding projects successful, we test baseline equation (1):

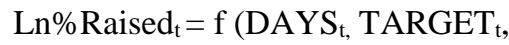
$\operatorname{lnNUMBINV}_{\mathrm{t}}$, TEAM $_{\mathrm{t}}, \ln$ VIEWS $_{\mathrm{t}}, \operatorname{lnFOLLOWERS}_{\mathrm{t}}$, $\operatorname{lnCOMPUP}_{\mathrm{t}}, \operatorname{lnINVDISC}_{\mathrm{t}}$ )

Since we have collected the data for only a limited period of time, we were not able to track the whole projects lifecycle. Therefore, we test the dynamics of the percentage amount raised $\left(\operatorname{Ln} \%\right.$ Raised $\left._{t}\right)$ during the period in question. According to the previous research, the collective attention effect creates the largest amount of investments during the first few days during the campaign [6]. Therefore, we include the variable $\mathrm{DAYS}_{\mathrm{t}}$ into the equation, to test whether the remaining number of days until the end of the campaign will affect change in the percentage amount raised. Large investors, venture capitalists, and/or business angel support contributes to the project's success $[5,14,15]$.

Therefore, we include the number of investors each day $\ln _{\text {NUMBINV }}$ in our model. Projects human capital influences successfulness of a project [11], and therefore we include variable $\mathrm{TEAM}_{\mathrm{t}}$, which accounts for the total number of the team members and we do not account for the gender differences. Since social networks have an influence on the formation of an investors attitude toward start-up and motivation to invest $[6,13,14]$, we account for lnVIEWS (number of project's views on day $t$ ), InFOLLOWERS (number of project's followers on day $t$ ), InCOMPUP (number of company updates on day $\mathrm{t}$ ), and InINVDISC (number of investors discussions on day $\mathrm{t}$ ).

Our sample consists of panel data. First and foremost, we need to run a few tests in order to determine an appropriate panel data model. Breusch and Pagan LM tests for random effects [16], is significant, which suggests that the random-effects model is preferred. Hausman test [16] is highly insignificant, suggesting again, that random effects model is the model we should implement into our analysis. We test for the autocorrelation in the data [17], and we find that it is present in our sample. Therefore, we use random effects model with robust standard errors. The empirical results are displayed in Table II.

TABLE II. EMPIRICAL RESULTS

\begin{tabular}{|l|l|}
\hline \multicolumn{1}{|c|}{ Variables } & \multicolumn{1}{|c|}{ Random effects model } \\
\hline DAYS & $-.00007474(.0011185)$ \\
\hline TARGET & $-2.03 \mathrm{e}-07^{*}(7.67 \mathrm{e}-08)$ \\
\hline lnNUMBINV & $.04468116^{*}(.080277)$ \\
\hline TEAM & $0.0964655^{* * *}(.0508882)$ \\
\hline lnVIEWS & $0.0078007(.0051892)$ \\
\hline lnFOLLOWERS & $-0.0546537(.0427847)$ \\
\hline lnCOMPUP & $0.0202063(.0305522)$ \\
\hline lnINVDISC & $-0.0342658(.0524084)$ \\
\hline _cons & $-2.598901(.3074292)$ \\
\hline overall R-sq Standard deviations of coefficients are presented in parenthesis. Statistical \\
significance: $* * * p<.10, * * p<.05, * p<.01$
\end{tabular}

From Table II, it can be seen that target amount specified, the number of the project's backers and the number of team members are significant in explaining the rise in the amount collected. Our findings are in accordance with the previous research.

\section{CONCLUSION}

Lukarinen et al. (2016) find that in equity crowdfunding, emotional and social criteria are more important to the investors than financial ones. Crowdfunding equity is not particularly interesting to the financial investors since it lacks long-term perspective, dividends, and voting rights.

Our research shows that larger entrepreneurial teams attract more investments. The larger the amount start-up is trying to raise it will discourage the investments. The more investors project has it will attract more investments. 
The limitation of this study is its very short time span, a few projects that are subject of this study, and a fact that all projects are from only one equity crowdfunding platform. Further studies should be directed toward analysis of different projects from various equity crowdfunding platforms, and much larger time series should be employed. Moreover, success factors may vary depending on the industry to which project belongs, and that could further diversify researches concerning equity crowdfunding.

\section{REFERENCES}

[1] D. M. Freedman and M. R. Nutting, Equity crowdfunding for investors: A guide to risks, funding portals, due diligence, and deal terms. New Jersey: John Wiley \& Sons, 2015.

[2] V. Bogojevic Arsic and M. Latinovic. "Alternative online finance: crowdfunding and ICO", Symorg 2018: Doing Business in the Digital Age: Challenges, Approaches and Solutions, Zlatibor, 2018.

[3] B. Z Zhang, R. Wardrop, T. Ziegler, A. Lui, J. Burthon, A. James, K. Garvey (2016). Sustaining Momentum, The 2nd European alternative finance industry report, Cambridge centre for alternative finance. Downloaded on 2nd of April, 2018. from https://www.jbs.cam.ac.uk/facultyresearch/centres/alternative-finance/publications/sustainingmomentum/\#.WsJs_C5ubIU

[4] W. E. Davies and E. Giovannetti, "Signalling experience \& reciprocity to temper asymmetric information in crowdfunding evidence from 10,000 projects", Technological Forecasting \& Social Change, ARTICLE IN PRESS. https://doi.org/10.1016/j.techfore.2018.03.011

[5] N. Vulkan, T. Astebro, and M. F. Sierra, "Equity crowdfunding: A new phenomenon," Journal of Business Venturing Insights, Vol. 5, 2016, pp. 37-49. http://dx.doi.org/10.1016/j.jbvi.2016.02.001

[6] L. Hornuf and A. Schwienbacher, "Market mechanisms and funding dynamics in equity crowdfunding," J Corp Finan,
Vol.
50
2018
$\mathrm{pp}$
556-574.

[7] M. Rossi, "The new ways to raise capital: An exploratory study of crowdfunding," Int J Fin Research, Vol. 5, No. 2, 2014, pp 8-18. doi:10.5430/ijfr.v5n2p8

[8] J. Paschen, "Choose wisely: crowdfunding through the stages of the startup life cycle," Business Horizons, Vol. 60, 2017, pp. 179-188. DOI: 10.1016/j.bushor.2016.11.003

[9] B. R. Barringer and R. D. Ireland, Entrepreneurship: successful launching new ventures, $5^{\text {th }}$ ed, USA: Pearson Education, Inc., 2016.

[10] X. Walthoff-Borm, A. Schwienbacherb, and T. Vanacker, "Equity crowdfunding: first resort or last resort," Journal of Business Venturing, Vol. 33, 2018, pp. 513-533. https://doi.org/10.1016/j.jbusvent.2018.04.001

[11] M. Barbi and S. Mattioli, "Human capital, investor trust, and equity crowdfunding," Research in International Business and Finance, Vol. 49, 2019, pp. 1-12. https://doi.org/10.1016/j.ribaf.2019.02.005

[12] M. Geiger and S. C. Oranburg, "Female entrepreneurs and equity crowdfunding in the US: Receiving less when asking for more," Journal of Business Venturing Insights, Vol. 10, e00099, 2018. https://doi.org/10.1016/j.jbvi.2018.e00099

[13] R. Brown, S. Mawson, and A. Rowe, "Start-ups, entrepreneurial networks and equity crowdfunding: A processual perspective," Industrial Marketing Management, IN PRESS. https://doi.org/10.1016/j.indmarman.2018.02.003

[14] A. Lukkarinen, J. E. Teich, H. Wallenius, J. Wallenius, "Success drivers of online equity crowdfunding campaign," Decision Support Systems, Vol. 87, 2016, pp. 26-38. http://dx.doi.org/10.1016/j.dss.2016.04.006

[15] S. Mamonov and R. Malaga, "Success factors in Title III equity funding in the United States," Electronic Commerce Research and Applications, Vol. 27, 2018, pp. 65-73. https://doi.org/10.1016/j.elerap.2017.12.001

[16] W. H. Green, Econometric analysis. 5th ed., New Jersey: Prentice Hall, 2002.

[17] J. M. Wooldridge, Econometric analysis of cross section and panel data. The MIT Press: Massachusetts, 2002. 